JAMP: Jurnal Adminitrasi dan Manajemen Pendidikan

Volume 2 Nomor 2 Juni 2019, Hal : 56-64

Tersedia Online di http://journal2.um.ac.id/index.php/jamp/

ISSN 2615-8574 (online)

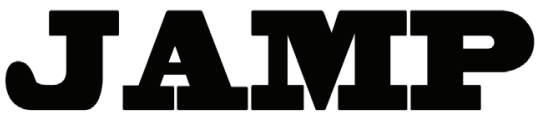

\title{
ANALISIS OKUPANSI LABORATORIUM KOMPUTER
}

\author{
Feni Tutut Wahyuningsih \\ Bambang Budi Wiyono \\ Wildan Zulkarnain \\ fenitututw03@gmail.com \\ Universitas Negeri Malang, Jl. Semarang 5 Malang 65145
}

\begin{abstract}
: the purpose of this research was to (1) count the efficiency times of computers in the Computer Laboratory at SMP Negeri 1 Pakis Malang; (2) find the occupancy rate of the Computer Laboratory at SMP Negeri 1 Pakis Malang; and (3) to estimate how much the loss of the occupancy rate of the Computer Laboratory at SMP Negeri 1 Pakis Malang are not met. The research method used is descriptive research with this type of quantitative research. Data analysis techniques used are descriptive analysis. The results of the study are (1) the level of effectiveness of computers included in the low category, (2) the level of the okupansi computer lab included in the middle category, (3) schools suffered a small loss due to occupancy not being met.
\end{abstract}

Keywords: occupancy; computer labs; school

\begin{abstract}
Abstrak: tujuan penelitian ini untuk (1) menghitung waktu daya guna komputer yang ada di Laboratorium Komputer di SMP Negeri 1 Pakis Kabupaten Malang; (2) menemukan tingkat okupansi Laboratorium Komputer di SMP Negeri 1 Pakis Kabupaten Malang; dan (3) melakukan estimasi berapa kerugian dari tingkat okupansi Laboratorium Komputer di SMP Negeri 1 Pakis Kabupaten Malang yang tidak terpenuhi. Metode penelitian yang digunakan yaitu penelitian deskriptif dengan jenis penelitian kuantitatif. Teknik analisis data yang digunakan yaitu analisis deskriptif. Hasil penelitian adalah (1) tingkat daya guna komputer termasuk dalam kategori rendah, (2) tingkat okupansi laboratorium komputer termasuk dalam kategori sedang, (3) sekolah mengalami sedikit kerugian akibat okupansi yang tidak terpenuhi.
\end{abstract}

Kata kunci: okupansi; laboratorium komputer; sekolah

Sarana dan prasarana merupakan hal yang penting dalam menunjang pendidikan dan menjadi pendukung proses kegiatan belajar-mengajar. Sesuai dengan ketentuan dari Departemen Pendidikan Nasional (dalam Barnawi \& Arifin, 2012: 47), sarana pendidikan adalah "semua perangkat peralatan, bahan, dan perabot yang secara langsung digunakan dalam proses pendidikan di sekolah, sedangkan prasarana pendidikan adalah semua perangkat kelengkapan dasar yang secara tidak langsung menunjang pelaksanaan proses pendidikan di sekolah". Berdasarkan pernyataan tersebut dapat disimpulkan, bahwa sarana dan prasarana pendidikan sangat penting dalam menunjang proses pendidikan di sekolah.

Laboratorium Komputer termasuk ke dalam salah satu contoh prasarana pendidikan di sekolah, karena secara tidak langsung Laboratorium Komputer menunjang kegiatan belajar-mengajar di sekolah. Laboratorium Komputer merupakan ruangan yang digunakan sebagai tempat praktik dalam mengembangkan keterampilan Teknologi Informasi dan Komunikasi (TIK) dan dalam akselerasi proses pembelajaran. Pembelajaran yang dilakukan di Laboratorium Komputer berupa pengoperasian komputer, pengolahan data, pengolahan angka, dan pengolahan presentasi serta aplikasi komputer lainnya. Laboratorium Komputer saat ini telah berkembang sangat pesat, tak jarang kita temukan tempat/ 
ruangan tersebut di sekolah-sekolah. Namun, penggunaan Laboratorium Komputer oleh peserta didik perlu dipantau/diawasi oleh guru maupun tenaga laboratorium yang ada di sekolah, karena jika tidak, akan berakibat fatal.

Pada kenyataannya penggunaan Laboratorium Komputer seringkali kurang optimal. Masih terdapat beberapa komputer di laboratorium komputer yang tidak digunakan yang disebabkan oleh keadaan tertentu. Hal tersebut peneliti ketahui ketika peneliti datang ke beberapa sekolah ketika melakukan kegiatan observasi untuk tugas mata kuliah sebelumnya. Terkadang laboratorium komputer juga tidak digunakan sehari penuh sesuai dengan jadwal pelajaran yang telah tersedia. Tanpa disadari hal tersebut dapat mengakibatkan kerugian. Namun, sekolah tidak menyadari kerugian yang diakibatkan oleh perihal tersebut. Hal tersebut yang menjadi alasan peneliti melakukan penelitian tentang occupancy rate. Dalam penelitian ini masalah yang akan diteliti, yaitu mengenai daya guna komputer yang ada di Laboratorium Komputer, daya guna ruang laboratorium komputer, dan penyebab komputer tidak digunakan serta menghitung kerugian atas okupansi yang tidak terpenuhi. Namun, peneliti menitik beratkan pada persoalan occupancy rate.

Caucheteux, Sabar \& Boucher (2013) mendefinisikan okupansi berkaitan dengan mengukur kinerja energi pada suatu bangunan gedung, semua tindakan dari penghuni akan mempengaruhi konsumsi energi. Parameter yang berbeda terkait dengan okupansi yaitu kehadiran, pencahayaan, membuka dan menutup ruang, penggunaan berbagai fasilitas, dan tindakan yang dilakukan. Tindakan yang dilakukan pengguna tergantung pada parameter hunian yang disebabkan oleh beberapa alasan. Okupansi tergantung pada beberapa faktor, diantaranya bangunan itu sendiri, lokasi dan orientasi, kemungkinan tindakan, penggunaan, adat istiadat dan kebiasaan pengguna, dan sebagainya. Okupansi kemudian dikhususkan untuk sebuah bangunan, situs, populasi tertentu, dan penggunaan tertentu. Setiap perubahan terhadap sebuah bangunan dapat menyebabkan perubahan dalam okupansi dan karenanya konsekuensi dari sudut pandang energi. Contoh, menambah fasilitas yang ada di suatu ruangan.

Penelitian tentang occupancy rate pernah dilakukan oleh beberapa peneliti sebelumnya. Primanty pada tahun 2010 melakukan penelitian yang berjudul Analisis Okupansi Komputer di Laboratorium Komputer Fakultas Ilmu Pendidikan Universitas Negeri Malang yang bertujuan untuk mengetahui tingkat Occupancy Rate komputer, jumlah komputer yang rusak, dan jumlah komputer cadangan didapatkan hasil penelitian, yaitu penghitungan Occupancy Rate komputer diperoleh dari jumlah waktu yang dipergunakan dibagi dengan jumlah waktu yang disediakan selama satu bulan dan hasilnya dikalikan 100\%. Setyawan pada tahun 2017 juga melakukan penelitian tentang analisis okupansi yang berjudul Analisis Okupansi Ruang Kuliah Pada Fakultas Ilmu Pendidikan Universitas Negeri Malang yang bertujuan untuk mengetahui tingkat daya guna ruang kuliah pada FIP UM, untuk mengetahui tingkat okupansi tempat duduk di ruang kuliah pada FIP UM, untuk mengetahui kerugian dari tingkat okupansi yang tidak terpenuhi, dan untuk mendeskripsikan penyebab ruang kuliah tidak digunakan.

Penelitian lain juga dilakukan oleh Solihin pada tahun 2017 yang berjudul The Optimization of Melati Type Hotel Occupancies: Case Study in Badung Regency, Bali yang bertujuan untuk membahas tentang upaya pengelolaan hotel berbintang yang dipasarkan melalui jalur pemesanan di Kabupaten Badung untuk memaksimalkan hunian hotel. Pada tahun 2012, Khaer dan Utomo menelakukan penelitian dengan judul Pengaruh Tingkat Hunian Pada Keputusan Investasi Proyek Hotel Santika Gubeng Surabaya yang bertujuan untuk analisis investasi mengenai tingkat okupansi agar bisa diketahui perubahan tingkat okupansi hotel yang terjadi, sehingga diketahui kelayakannya. Pada tahun 2016, Juhari juga melakukan penelitian yang berjudul Analisis Harga Terhadap Room Occupancy Hotel dan Penginapan di Kota Pangkalpinang yang bertujuan untuk mengetahui pengaruh analisis harga terhadap room occupancy pada hotel dan penginapan di Kota Pangkalpinang. Perbedaan penelitian yang dilakukan peneliti dengan penelitian terdahulu yaitu terletak pada objek serta lokasi yang akan diteliti.

Lokasi penelitian yang diteliti yaitu di SMP Negeri 1 Pakis Kabupaten Malang. Tepatnya pada laboratorium komputer yang ada di SMP Negeri 1 Pakis. Penelitian ini bertujuan untuk menghitung waktu daya guna komputer yang ada di Laboratorium Komputer di SMP Negeri 1 Pakis Kabupaten Malang, menemukan tingkat okupansi Laboratorium Komputer di SMP Negeri 1 Pakis Kabupaten 
Malang dan melakukan estimasi berapa kerugian dari tingkat okupansi Laboratorium Komputer di SMP Negeri 1 Pakis Kabupaten Malang yang tidak terpenuhi.

\section{METODE}

Penelitian ini menggunakan penelitian deskriptif dengan jenis penelitian kuantitatif. Alasan peneliti menggunakan penelitian kuantitatif karena data yang akan dikumpulkan yaitu berupa angka yang kemudian akan diolah untuk menemukan hasil dari tingkat okupansi Laboratorium Komputer. Jenis desain penelitian yang digunakan, yaitu deskriptif, dimana peneliti mengumpulkan data atau fakta mengenai waktu penggunaan komputer di Laboratorium Komputer pada saat peneliti melakukan penelitian, kemudian data tersebut diolah serta dianalisis dan dideskripsikan. Dengan demikian desain dan jenis penelitian ini adalah deskriptif non-korelasional. Tingkat okupansi sebagai variabel dan estimasi kerugian dalam bentuk uang merupakan variabel lainnya yang tidak diuji korelasinya. Variabel terikat dalam penelitian ini, yaitu tingkat okupansi dan kerugian. Sedangkan variabel bebasnya adalah komputer, listrik, user (pengajar, pengelola Laboratorium Komputer, peserta didik), program pengajaran, seperangkat tempat komputer, jadwal, presensi, programmer, dan teknisi.

Populasi dalam penelitian ini yaitu seluruh jumlah komputer yang ada di laboratorium komputer SMP Negeri 1 Pakis sebanyak 41 komputer. Pada penelitian ini tidak membutuhkan sampel karena termasuk sensus. Jadi, seluruh populasi digunakan dalam penelitian ini. Cara pengambilan data pada penelitian ini, yaitu menggunakan time series. Dalam pengambilan data, peneliti mengambil data di waktu yang berbeda.

Prosedur penelitian dilakukan melalui tiga tahapan yaitu tahap persiapan, tahap pelaksanaan, dan tahap penyusunan laporan. Pada tahap persiapan peneliti melakukan beberapa kegiatan, yaitu penentuan judul penelitian, menyusun rancangan penelitian, studi pendahuluan, dan mengurus perijinan penelitian. Sedangkan pada tahap pelaksanaan peneliti terjun langsung ke lapangan untuk melakukan penelitian. Kemudian pada tahap terakhir yaitu tahap penyusunan laporan dilakukan ketika data penelitian telah dikumpulkan seluruhnya. Laporan disusun sesuai dengan arahan dari kedua pembimbing skripsi.

Sumber data pada penelitian ini ada dua, yaitu sumber data primer dan sumber data sekunder. Sumber data primer diperoleh dengan cara mengamati secara langsung penggunaan komputer pada Laboratorium Komputer di SMP Negeri 1 Pakis Kabupaten Malang. Sedangkan sumber data sekunder diperoleh dari petugas Laboratorium Komputer di SMP Negeri 1 tersebut dan guru mata pelajaran serta dari dokumen penunjang. Data estimasi kerugian didapatkan setelah diketahui tingkat okupansi Laboratorium Komputer dengan membandingkan harga sewa komputer saat ini di tempat-tempat persewaan komputer atau warnet.

Teknik pengumpulan data yang digunakan peneliti dalam penelitian ini, yaitu teknik observasi, wawancara, dan dokumentasi. Dalam teknik observasi, peneliti mengamati selama kegiatan belajarmengajar efektif berlangsung di Laboratorium Komputer. Peneliti mengamati berapa banyak komputer yang terpakai dan tidak terpakai serta berapa lama komputer digunakan. Dalam teknik wawancara, peneliti memperoleh data dengan cara menggali informasi melalui guru mata pelajaran TIK yang sekaligus menjadi penanggung jawab laboratorium komputer. Wawancara dilakukan ketika apa yang dilihat belum sepenuhnya dapat memenuhi data yang diperlukan oleh peneliti. Wawancara yang dilakukan peneliti merupakan teknik wawancara informal atau tidak resmi, karena wawancara dilakukan di sela jam pelajaran berlangsung atau melalui chat di media sosial. Dalam teknik dokumentasi, peneliti melihat waktu penggunaan komputer di Laboratorium Komputer melalui presensi penggunaan komputer yang peneliti sediakan. Peneliti juga meminta jadwal pelajaran kepada guru mata pelajaran TIK guna menyelaraskan antara presensi dengan jadwal yang seharusnya Laboratorium Komputer digunakan.

Teknik analisis data yang digunakan dalam penelitian ini yaitu analisis deskriptif yang didalamnya juga terdapat distribusi frekuensi berupa persentase. Analisis data dilakukan pada aplikasi microsoft excel, dimana peneliti membuat tabel kemudian memasukkan data waktu penggunaan yang diperoleh 
dari hasil penelitian yang dilakukan kemudian data tersebut dihitung menggunakan rumus occupancy rate. Berikut rumus untuk menghitung tingkat daya guna komputer.

$$
\text { Rata tingkat daya guna komputer }=\frac{\text { Jumlah waktu komputer terpakai }}{\text { Jumlah waktu komputer tersedia }} \times 100 \%
$$

Sedangkan rumus untuk menghitung tingkat okupansi laboratorium komputer adalah sebagai berikut.

$$
\text { Tingkat okupansi lab komputer }=\frac{\text { Jumlah komputer terpakai }}{\text { Jumlah komputer tersedia }} \times 100 \%
$$

Setelah diketahui persentase tingkat okupansi komputer dan laboratorium komputer, maka ditarik kesimpulan untuk kategori tingkat okupansi tersebut. Kriteria penarikan kesimpulan yaitu dengan menentukan panjang interval dari kategori tinggi, sedang, dan rendah. Setelah diketahui occupancy rate komputer, maka dapat diketahui pula vacancy rate atau tingkat okupansi yang tidak terpenuhi. Kemudian dapat dihitung nilai kerugian yang disebabkan oleh tingkat okupansi yang tidak terpenuhi dengan rumus sebagai berikut.

\section{Estimasi kerugian $=\mathrm{OH} \mathrm{x}$ harga sewa komputer di warnet}

Keterangan:

$\mathrm{OH}=$ tingkat okupansi tidak terpenuhi

\section{HASIL}

\section{Tingkat Daya Guna Komputer}

Kegiatan penelitian yang dilakukan peneliti untuk mengumpulkan data dilakukan selama enam bulan yaitu pada tanggal 8 Januari 2018 sampai dengan 24 Juni 2018 dengan estimasi waktu 1 bulan terdiri dari 4 minggu. Waktu penelitian dibedakan pada empat bulan awal dan dua bulan terakhir karena pada dua bulan terakhir pengguna laboratorium komputer yaitu kelas 9 sudah tidak lagi terdapat pembelajaran TIK. Pada empat bulan awal waktu penelitian 3680 menit x 41 komputer $=150880$ menit (2514 jam 40 menit) selama 1 bulan. Pada perhitungan bulan kelima dan keenam, waktu penggunaan ideal hanya 5 jam pelajaran atau 200 menit x $41=8200$ menit dalam satu minggu. Sehingga jika dihitung per bulan waktu ideal penggunaan komputer 8200 menit x $4=32800$ menit (546 jam 40 menit). Perhitungan selama 1 bulan digunakan untuk mengetahui seberapa besar daya guna komputer, okupansi laboratorium komputer, estimasi kerugian dari tingkat okupansi yang tidak terpenuhi dan hal-hal yang menyebabkan laboratorium komputer tidak digunakan. Berikut rincian occupancy rate komputer setiap bulan selama enam bulan.

\begin{tabular}{|c|c|c|c|c|}
\hline \multirow{2}{*}{ Bulan Ke } & \multicolumn{2}{|c|}{ Waktu Pemakaian } & \multirow{2}{*}{ Waktu Tersedia } & \multirow{2}{*}{ Occupancy Rate } \\
\hline & Jam Pelajaran & Menit & & \\
\hline 1 & 2191 & 87640 & 150880 & $58 \%$ \\
\hline 2 & 1514 & 60560 & 150880 & $40 \%$ \\
\hline 3 & 848 & 33920 & 150880 & $22 \%$ \\
\hline 4 & 1312 & 52480 & 150880 & $35 \%$ \\
\hline 5 & 0 & 0 & 32800 & $0 \%$ \\
\hline 6 & 0 & 0 & 32800 & $0 \%$ \\
\hline Total & 5865 & 234600 & 669120 & $35 \%$ \\
\hline Rata-rata & 977,5 & 39100 & 111520 & $35 \%$ \\
\hline
\end{tabular}

Tabel 1. Rincian Data Occupancy Rate Komputer Selama 6 Bulan 
Berdasarkan Tabel 1, dapat diketahui occupancy rate komputer tertinggi terletak pada bulan pertama dengan nilai sebesar 58\%. Sedangkan occupancy rate komputer terendah terletak pada bulan kelima dan keenam dengan nilai sebesar 0\%. Dapat disimpulkan dari Tabel 1 bahwa occupancy rate komputer setiap bulannya mengalami penurunan. Hasil akhir dari data penelitian dapat diketahui bahwa occupancy rate komputer selama 6 bulan sebesar 35\%. Berikut occupancy rate selama 6 bulan jika disajikan dalam bentuk diagram.

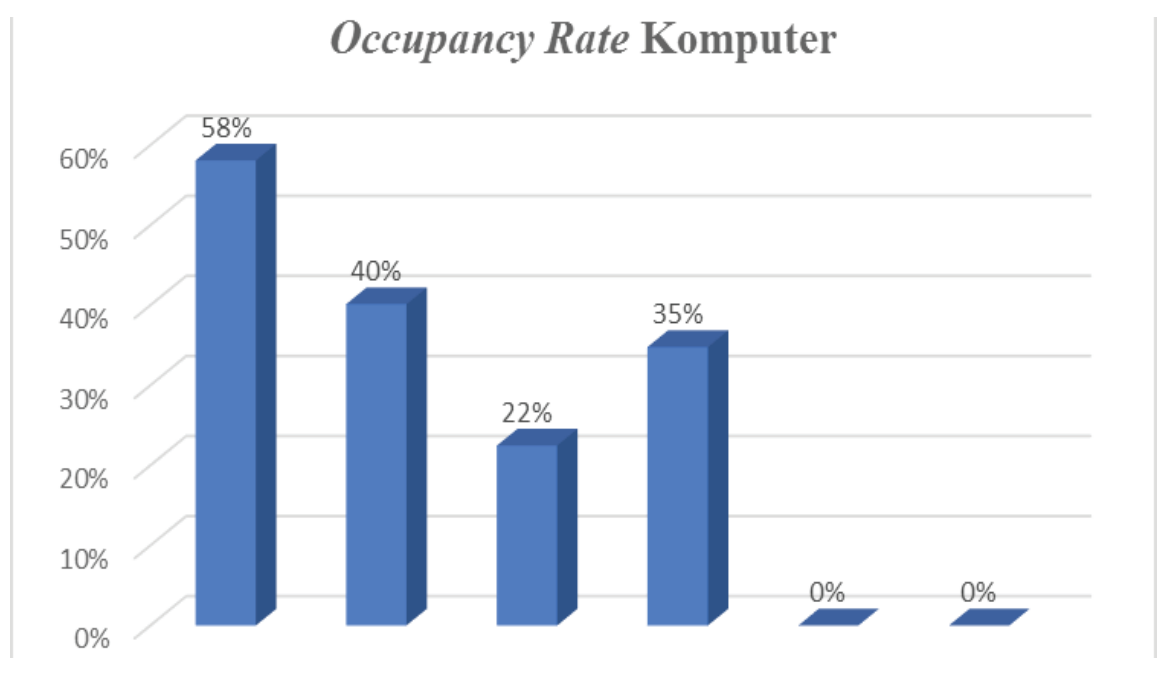

Gambar 1. Diagram Tingkat Occupancy Rate Komputer Selama 6 Bulan

\section{Tingkat Okupansi Ruang Laboratorium Komputer}

Setelah menentukan occupancy rate komputer di laboratorium komputer, maka tahap selanjutnya yaitu menentukan occupancy rate ruang laboratorium komputer. Waktu penelitian pada empat bulan awal yang dilakukan yaitu selama 3680 x 4 bulan $=14720$ menit (245 jam 20 menit). Sedangkan waktu penelitian pada dua bulan terakhir yang dilakukan yaitu selama $800 \times 2$ bulan $=1600$ menit (26 jam 40 menit). Ruang laboratorium komputer di SMP Negeri 1 Pakis hanya terdapat 1 ruang. Di dalam ruang laboratorium komputer tersedia 41 unit komputer. Berikut diagram tingkat occupancy rate ruang laboratorium komputer selama enam bulan.

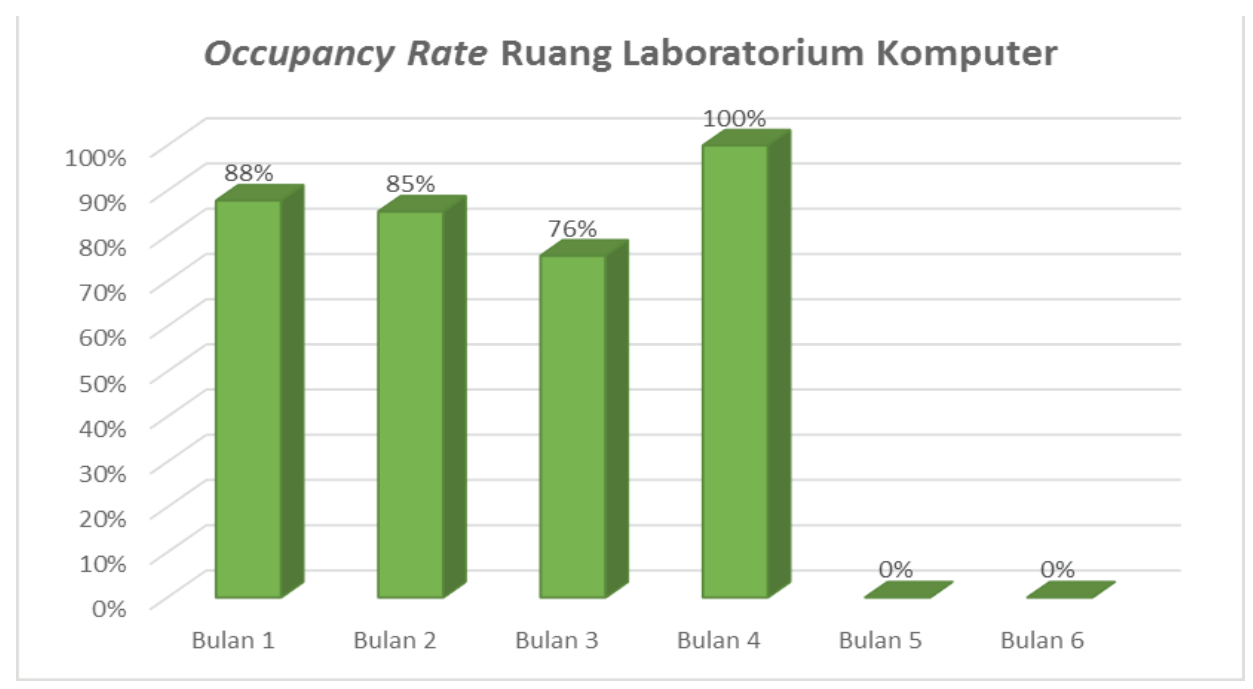

Gambar 2. Diagram Tingkat Occupancy Rate Ruang Laboratorium Komputer Selama 6 Bulan 
Berdasarkan Gambar 2 dapat dilihat bahwa occupancy rate ruang laboratorium komputer selama dua bulan terakhir sangat rendah. Tingkat okupansi paling tinggi terletak pada bulan keempat. Hal ini dikarenakan pada bulan kelima dan keenam laboratorium komputer tidak digunakan untuk kegiatan pembelajaran. Setelah kegiatan UNBK (Ujian Nasional Berbasis Komputer), dilakukan pemulihan sistem pada komputer-komputer yang ada di laboratorium komputer. Seluruh komputer yang ada di laboratorium komputer diinstall ulang dikarenakan komputer terkena virus akibat sering digunakan untuk mendownload kelengkapan UNBK, sehingga banyak aplikasi yang error. Pembelajaran TIK lebih difokuskan pada pendalaman teori dan latihan soal untuk persiapan ujian akhir semester. Sedangkan pada bulan keempat tingkat okupansi tinggi dikarenakan pada bulan keempat komputer digunakan seluruhnya untuk kegiatan UNBK.

\section{Analisis Perkiraan Kerugian dari Tingkat Okupansi yang Tidak Terpenuhi}

Estimasi kerugian dari tingkat okupansi yang tidak terpenuhi dapat dihitung setelah diketahui berapa waktu yang terbuang sia-sia selama 6 bulan. Untuk mengetahui kerugian waktu dapat dihitung menggunakan teknik vacancy rate. Rumus yang digunakan peneliti yaitu waktu pemakaian ideal dikurangi dengan waktu pemakaian sesuai dengan data hasil penelitian yang diperoleh peneliti. Waktu pemakaian ideal selama 6 bulan sebesar 669120 menit (11152 jam), sedangkan waktu pemakaian sesuai dengan data hasil penelitian yang diperoleh peneliti. Berikut tabel rincian data occupancy rate yang tidak terpenuhi.

Tabel 2. Rincian Data Occupancy Rate yang Tidak Terpenuhi

\begin{tabular}{ccccc}
\hline \multirow{2}{*}{ Bulan Ke } & $\begin{array}{c}\text { Data Hasil } \\
\text { Observasi }\end{array}$ & Pemakaian Ideal & Menit & Jam \\
\cline { 4 - 5 } 1 & 87640 & 150880 & 63240 & 1054 \\
2 & 60560 & 150880 & 90320 & 1505 \\
3 & 33920 & 150880 & 116960 & 1949 \\
4 & 52480 & 150880 & 98400 & 1640 \\
5 & 0 & 32800 & 32800 & 546,67 \\
6 & 0 & 32800 & 32800 & 546,67 \\
\hline Total & $\mathbf{2 3 4 6 0 0}$ & $\mathbf{6 6 9 1 2 0}$ & $\mathbf{4 3 4 5 2 0}$ & $\mathbf{7 2 4 2}$ \\
\hline Rata-rata & $\mathbf{3 9 1 0 0}$ & $\mathbf{1 1 1 5 2 0}$ & $\mathbf{7 2 4 2 0}$ & $\mathbf{1 2 0 7}$ \\
\hline
\end{tabular}

Perhitungan kerugian dalam bentuk rupiah dapat dilakukan dengan mengkalikan total kerugian dengan harga sewa komputer sesuai dengan data hasil pengamatan yang diperoleh peneliti di lima warnet yaitu sebesar Rp 3.000/jam. Berdasarkan perhitungan rata-rata kerugian selama 6 bulan diketahui persentase kerugian sebesar $65 \%$. Namun, persentase tersebut tidak termasuk dalam kategori tinggi karena terdapat alasan yang logis mengapa persentase kerugian bisa mencapai $65 \%$. Hal tersebut dikarenakan pada bulan kelima dan keenam komputer di laboratorium komputer mengalami pemulihan sistem akibat telah digunakan untuk kegiatan UNBK. Komputer banyak yang terkena virus sehingga banyak aplikasi yang tidak bisa dijalankan. Pembelajaran TIK pada dua bulan teakhir difokuskan pada pendalaman teori dan latihan soal untuk persiapan ujian akhir semester. Jadi, dapat disimpulkan bahwa sekolah mengalami sedikit kerugian.

\section{PEMBAHASAN}

\section{Tingkat Daya Guna Komputer}

Berdasarkan Gambar 1 dapat diketahui bahwa selama 3 bulan pertama, tingkat occupancy rate komputer mengalami penurunan setiap bulannya. Kemudian pada bulan keempat, tingkat occupancy 
rate komputer mengalami kenaikan yaitu sebesar 13\%. Kemudian pada bulan kelima sampai dengan bulan keenam tingkat occupancy rate komputer turun drastis menjadi $0 \%$. Hal tersebut dikarenakan peserta didik tidak melaksanakan pembelajaran di laboratorium komputer dan hanya melaksanakan pembelajaran di ruang kelas untuk pendalaman materi serta mengerjakan latihan soal untuk persiapan ujian akhir semester. Sedangkan komputer yang ada di laboratorium komputer dalam tahap pemulihan sistem setelah digunakan kegiatan UNBK. Pemulihan sistem tersebut dilakukan untuk membersihkan virus komputer agar sistem komputer berjalan lancar kembali. Sehingga, jika dirata-rata selama 6 bulan, tingkat occupancy rate komputer sebesar 35\% dengan penggunaan komputer sebesar 234600 menit (3910 jam). Sehingga, dapat disimpulkan bahwa tingkat occupancy rate komputer selama 6 bulan di laboratorium komputer SMP Negeri 1 Pakis termasuk ke dalam kategori rendah. Rendahnya tingkat okupansi tidak semata-mata dikarenakan kelalaian pihak sekolah. Namun, dalam kegiatan pembelajaran tidak setiap pembelajaran harus menggunakan komputer karena ketika penjelasan materi hanya guru mata pelajaran yang menggunakan komputer dan mendemokan praktik dari materi yang dijelaskan melalui LCD, sehingga peserta didik hanya perlumemperhatikan serta memahaminya. Kemudian dipertemuan selanjutnya peserta didik mempraktikan materi yang telah dijelaskan dipertemuan sebelumnya. Perhitungan dilakukan sesuai dengan teori yang dijelaskan oleh Clark (dalam Davidson, Tanpa Tahun: 3 ) bahwa dalam menghitung tingkat okupansi yaitu dengan cara membagi molekul yang diterima dengan daya tampung maksimal molekul kemudian dikalikan 100\%. Hal ini juga dijelaskan pada penelitian yang dilakukan Primanty pada tahun 2010 bahwa penghitungan Occupancy Rate komputer diperoleh dari jumlah waktu yang dipergunakan dibagi dengan jumlah waktu yang disediakan selama satu bulan dan hasilnya dikalikan 100\%. Tingkat occupancy rate komputer rendah disebabkan oleh jumlah peserta didik setiap kelas lebih sedikit daripada jumlah komputer yang tersedia di ruang laboratorium komputer, sehingga tidak semua komputer terpakai selama kegiatan pembelajaran berlangsung. Selain itu, biasanya terdapat jam kosong yang menyebabkan ruang laboratorium komputer tidak digunakan serta adanya hari libur.

\section{Tingkat Okupansi Ruang Laboratorium Komputer}

Penggunaan ruang laboratorium komputer dapat dilihat dari penggunaan komputer yang ada di laboratorium komputer. Hal ini dikarenakan ruang laboratorium digunakan untuk kegiatan pembelajaran secara praktik. Tingkat okupansi ruang laboratorium komputer dikatakan efektif ketika komputer yang tersedia digunakan seluruhnya. Komputer yang tersedia di ruang laboratorium komputer sebanyak 41 unit. Sedangkan, pada kenyataannya komputer yang tersedia tidak digunakan seluruhnya. Hal ini dikarenakan jumlah peserta didik per kelas sebanyak 30 peserta didik, sehingga komputer yang digunakan sebanyak 30 unit komputer. Namun, setiap harinya pasti terdapat peserta didik yang tidak masuk. Sehingga, menyebabkan menurunnya tingkat okupansi ruang laboratorium komputer.

Berdasarkan Gambar 2 dapat diketahui bahwa tingkat okupansi tertinggi terletak pada bulan keempat. Sedangkan, tingkat okupansi terendah terletak pada bulan kelima dan bulan keenam. Pada tiga bulan pertama tingkat okupansi mengalami penurunan. Sedangkan, pada bulan keempat tingkat okupansi meningkat menjadi 100\%. Hal tersebut dikarenakan pada bulan keempat komputer digunakan seluruhnya untuk kegiatan UNBK. Pada bulan kelima dan keenam ruang laboratorium tidak digunakan untuk kegiatan pembelajaran. Sehingga, tingkat okupansi menjadi 0\% selama dua bulan terakhir. Sama halnya dengan alasan rendahnya tingkat daya guna komputer di laboratorium komputer pada dua bulan terakhir bahwa laboratorium komputer pada dua bulan terakhir tidak digunakan untuk kegiatan pembelajaran dikarenakan pemulihan komputer setelah digunakan untuk kegiatan UNBK serta pembelajaran peserta didik dilaksanakan di ruang kelas dan difokuskan pada latihan-latihan soal untuk persiapan ujian akhir semester. Gambar 2 mennggambarkan tingkat okupansi per bulan. Sehingga, berdasarkan diagram tersebut dapat dihitung rata-rata occupancy rate ruang laboratorium komputer selama 6 bulan yaitu sebesar 59\%. Jadi, dapat disimpulkan bahwa tingkat okupansi ruang laboratorium komputer di SMP Negeri 1 Pakis termasuk pada kategori sedang. Perhitungan tersebut didasarkan atas 
teori dari Shite (dalam Juhari, 2016: 6) bahwa tingkat hunian dapat dihitung berdasarkan persentase dengan menggunakan cara, jumlah hunian yang berpenghuni atau terisi dibagi dengan total hunian keseluruhan (room available) kemudian dikalikan dengan 100\%.

\section{Analisis Perkiraan Kerugian dari Tingkat Okupansi yang Tidak Terpenuhi}

Total kerugian waktu pada bulan pertama sebesar 63240 menit, bulan kedua sebesar 90320 menit, bulan ketiga 116960 menit, bulan keempat sebesar 98400 menit, serta pada bulan kelima dan bulan keenam masing-masing sebesar 32800 menit. Jika ditotal selama 6 bulan kerugian waktu sebesar 434520 menit (7242 jam).

Berdasarkan perhitungan rata-rata kerugian selama 6 bulan diketahui persentase kerugian sebesar $65 \%$. Namun, persentase tersebut tidak termasuk dalam kategori tinggi karena terdapat alasan yang logis mengapa persentase kerugian bisa mencapai $65 \%$. Hal tersebut dikarenakan pada bulan kelima dan keenam komputer di laboratorium komputer mengalami pemulihan sistem akibat telah digunakan untuk kegiatan UNBK. Komputer banyak yang terkena virus sehingga banyak aplikasi yang tidak bisa dijalankan. Pembelajaran TIK pada dua bulan teakhir difokuskan pada pendalaman teori dan latihan soal untuk persiapan ujian akhir semester. Jadi, dapat disimpulkan bahwa sekolah mengalami sedikit kerugian.

Terdapat beberapa faktor yang menyebabkan rendahnya tingkat occupancy rate komputer. Penyebab utama yaitu ruang laboratorium komputer tidak digunakan secara efektif dan efisien. Meskipun sudah terdapat jadwal yang telah disusun oleh pihak yang bersangkutan, kegiatan belajar-mengajar terkadang tidak terlaksana sesuai dengan jadwal karena alasan tertentu. Faktor-faktor tersebut yaitu guru mata pelajaran ijin tidak masuk dikarenakan ada kegiatan MGMP, ada kegiatan workshop di sekolah yang diikuti oleh guru-guru, ada kegiatan try out, Ujian Tengah Semester (UTS) tulis yang dikerjakan di kelas masing-masing, persiapan untuk Ujian Nasional Berbasis Komputer (UNBK), dan pemulihan komputer setelah digunakan untuk UNBK. Pemulihan dilakukan untuk membersihkan komputer dari virus akibat sering digunakan untuk mendonwload perlengkapan UNBK.

\section{SIMPULAN DAN SARAN Simpulan}

Tingkat daya guna komputer di laboratorium komputer SMP Negeri 1 Pakis selama 6 bulan mencapai $35 \%$ yang tergolong occupancy rate rendah. Rincian occupancy rate komputer dapat diketahui pada Tabel 1 (a) Selama 3 bulan pertama, tingkat occupancy rate komputer mengalami penurunan setiap bulannya, (b) pada bulan keempat, tingkat occupancy rate komputer mengalami kenaikan yaitu sebesar $13 \%$, (c) pada bulan kelima sampai dengan bulan keenam tingkat occupancy rate komputer turun drastis menjadi $0 \%$. Hal tersebut dikarenakan peserta didik tidak melaksanakan pembelajaran di laboratorium komputer dan hanya melaksanakan pembelajaran di ruang kelas untuk pendalaman materi serta mengerjakan latihan soal untuk persiapan ujian akhir semester. Sedangkan komputer yang ada di laboratorium komputer dalam tahap pemulihan sistem setelah digunakan kegiatan UNBK. Pemulihan sistem tersebut dilakukan untuk membersihkan virus komputer agar sistem komputer berjalan lancar kembali.

Tingkat okupansi ruang laboratorium komputer SMP Negeri 1 Pakis selama 6 bulan mencapai $59 \%$ yang tergolong occupancy rate sedang. Rincian occupancy rate dapat diketahui pada Gambar 2. (a) tingkat okupansi tertinggi terletak pada bulan keempat yaitu sebesar $100 \%$, (b) Pada tiga bulan pertama tingkat okupansi mengalami penurunan, (c) pada bulan kelima dan keenam ruang laboratorium tidak digunakan untuk kegiatan pembelajaran, sehingga occupancy rate sebesar 0\%. Sama halnya dengan alasan rendahnya tingkat daya guna komputer di laboratorium komputer pada dua bulan terakhir bahwa laboratorium komputer pada dua bulan terakhir tidak digunakan untuk kegiatan pembelajaran dikarenakan pemulihan komputer setelah digunakan untuk kegiatan UNBK serta pembelajaran peserta didik dilaksanakan di ruang kelas dan difokuskan pada latihan-latihan soal untuk persiapan ujian akhir semester. 
Estimasi kerugian dalam bentuk rupiah diperlukan perubahan sistem jam dari 1 jam $=40$ menit menjadi 1 jam $=60$ menit. Perhitungan kerugian dalam bentuk rupiah dibandingkan dengan harga sewa komputer di warnet yaitu sebesar Rp 3.000 per jam. Persentase kerugian selama 6 bulan sebesar 65\%. Tingginya persentase kerugian disebabkan oleh tidak digunakannya komputer selama dua bulan terakhir setelah kegiatan UNBK berlangsung. Setelah kegiatan UNBK, dilakukan pemulihan sistem pada komputer-komputer yang ada di laboratorium komputer. Seluruh komputer yang ada di laboratorium komputer diinstall ulang dikarenakan komputer terkena virus akibat sering digunakan untuk mendownload kelengkapan UNBK, sehingga banyak aplikasi yang error. Pembelajaran TIK lebih difokuskan pada pendalaman teori dan latihan soal untuk persiapan ujian akhir semester. Terkadang terdapat jam kosong sehingga laboratorium sekolah tidak digunakan. Jadi, dapat disimpulkan bahwa sekolah hanya mengalami sedikit kerugian. Ada beberapa hal yang menyebabkan ruang laboratorium komputer di SMP Negeri 1 Pakis tidak digunakan, yaitu guru mata pelajaran ijin tidak masuk dikarenakan ada kegiatan MGMP, ada kegiatan workshop di sekolah yang diikuti oleh guruguru, ada kegiatan try out, UTS tulis yang dikerjakan di kelas masing-masing, persiapan untuk UNBK, pemulihan komputer setelah digunakan untuk UNBK. Pemulihan dilakukan untuk membersihkan komputer dari virus akibat sering digunakan untuk mendonwload perlengkapan UNBK.

\section{Saran}

Bagi Peneliti selanjutnya diharapkan agar penelitian ini dapat dikembangkan pada penelitian berikutnya dengan skala atau lingkup yang lebih luas. Penelitian ini belum sepenuhnya mengupas kerugian pada tiap-tiap fasilitas yang ada di laboratorium komputer secara detail, karena hanya dihitung melalui waktu penggunaan komputer.

\section{DAFTAR RUJUKAN}

Barnawi \& Arifin, M. 2012. Manajemen Sarana dan Prasarana Sekolah. Yogyakarta: Ar-Ruzz Media.

Caucheteux, A., Sabar, A.E. \& Boucher, V. 2013. Occupancy Measurement in Building: A Litterature Review, Application on An Energy Efficiency Research Demonstrated Building. International Journal of Metrology and Quality Engineering, (Online), Jilid 4, No. 4, (https://www.metrology-journal.org), diakses 20 Maret 2019.

Davidson. Tanpa Tahun. Medicainal Chemistry, (Online), (https://courses.edx.org/c4x/DavidsonX/001x/asset/ Ch_5_clip_3_summary.pdf), diakses 21 November 2017.

Khaer, A.A. \& Utomo, C. 2012. Pengaruh Tingkat Hunian Pada Kepuasan Investasi Proyek Hotel Santika Gubeng Surabaya. Jurnal Teknik ITS, (Online), Jilid 1, No. 1, (http://digilib.its.ac.id), diakses 2 Desember 2017.

Juhari. 2016. Analisis Harga Terhadap Room Occupancy Hotel dan Penginapan di Kota Pangkalpinang. Jurnal Bisnis Darmajaya, (Online), Jilid 2, No. 2, (https://jurnal.darmajaya.ac.id/index.php/JurnalBisnis/article/ download/), diakses 6 Maret 2019.

Primanty, A. 2010. Analisis Okupansi Komputer di Laboratorium Komputer Fakultas Ilmu Pendidikan Universitas Negeri Malang. Skripsi tidak diterbitkan. Malang: FIP UM.

Setyawan, J.N. 2017. Analisis Okupansi Ruang Kuliah Pada Fakultas Ilmu Pendidikan Universitas Negeri Malang. Skripsi tidak diterbitkan. Malang: FIP UM.

Solihin. 2017. The Optimization of Melati Type Hotel Occupancies: Case Study in Badung Regency, Bali. Sushum Jurnal Sosial dan Humaniora, (Online), Jilid 8, No. 2, (http://ojs.pnb.ac.id/index.php/SOSHUM/article/ view/558/490), diakses 7 Maret 2019. 